ACTA THERIOLOGICA

Vol. 25, 25: 325-331, 1980

\title{
The Diet and Growth of Fox-Cubs in Two Regions of Scotland
}

\author{
H. H. KOLB \& R. HEWSON
}

Kolb H. H. \& Hewson R., 1980: The diet and growth of fox cubs in two regions of Scoland. Acta theriol., 25,25: 325-331 [With 3 Tables \& 2 Figs.]

Analysis of stomach contents showed that in North-east Scotland fox cubs are mainly fed on rabbits and hares, whereas in the West of Scotland they are fed on lambs and voles. The rate of growth of litters is the same in the two regions, but cubs in the West are born on average between a week and a fortnight later than those in the North-east. It is suggested that this is due to different periods of availability of the main foods in the two habitats.

[Department of Agriculture and Fisheries for Scotland, Agricultural Scientific Servichs, East Craigs, Edinburgh, EH12 8NJ, Scotland]

\section{INTRODUCTION}

Foxes Vulpes vulpes (Linnaeus, 1758) live in a great variety of habitats and eat a wide range of foods. The way in which populations adapt to these local circumstances is poorly understood. Previous work on foxes in Scotland has described the food, changes in density and reproductive condition of adults (Kolb \& Hew Son, 1979, 1980). This paper presents some information on the diet, date of birth and growth of fox cubs in two parts of Scotland and discusses the possible role of food availability in determining variations in the breeding and development of foxes .

\section{MATERIAL AND METHODS}

Litters of cubs killed during normal fox control operations were collected from gamekeepers, forestry rangers and shepherds between 1971 and 1976 . One sample came from North-east Scotland (Grampian), an area of moorland, forestry and lowland farming. The other came from the West of Scotland (Strathclyde and parts of Central and Highland), an area of forestry, upland sheep farming and deer forest, No significant differences were found in diet or growth within these areas so that they represent two homogeneous samples from either side of Scotland (see Fig. 1, K o l b \& H e w S o n, 1979).

All data came from litters killed on a known date. Each cub was weighed and measured from the top of the snout to the root of the tail (head and body length). The animal was then autopsied and its stomach contents identified as described in $\mathrm{Kolb}$ \& $\mathrm{Hews}$ on (1979). In the analysis of diets the litter was taken as the sampling unit. Results are presented as the percentage frequency

4-Acta Theriologica

[325] 


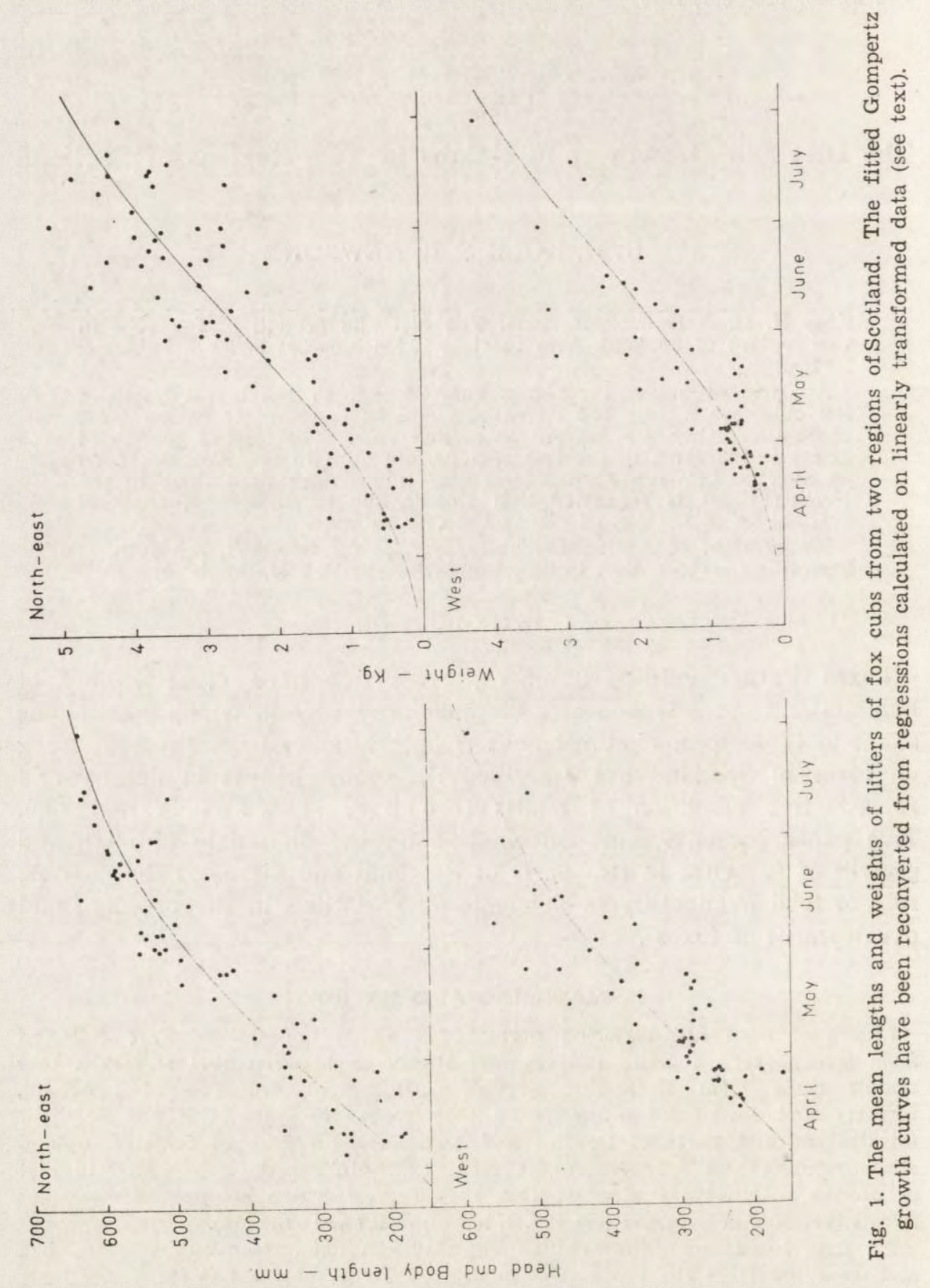


of occurrence of foods as the main item in the stomachs of litters of cubs and as the total occurrences of food items in a sample of litters.

Growth was analysed by transforming all data to a linear relationship through the use of conversion factors (Ricklefs, 1967). The transformed data were then tested by standard regression techniques. Three growth models were available: the Logistic, Gompertz and von Bertalanffy curves. The best model was chosen ky finding that curve which gave the largest proportion of common variance from the correlation between the transformed data and time. This proved to be the Gompertz curve, although the differences between it and the von Bertalanffy were small, both giving $r^{2}$ between 80 and $85 \%$. Assymptotes were estimated from the weights and head and body lengths of large samples of adult foxes killed in the same areas. Litter values higher than $90 \%$ of the assymptote were excluded from the analysis because of the sensitivity of the conversion factors in this range to deviations from the estimated assymptotes. All growth data have been presented as mean litter values, irrespective of sex. There was no difference in the sex ratio of cubs in the two areas and the lumped data allow a better comparison of growth rate and estimated mean date of birth. As the season progressed fewer whole litters and more individual cubs were received, leading to a slight spreading in the distribution weights and lengths (Fig. 1).

In order to estimate the age of litters and dates of birth it has been necessary to assume a standard length and weight at birth. From data in La y ne \& McKeon (1956) and EWer (1973), and from the comparison of weight and head and body length in this study, birth weight has been taken to be $100 \mathrm{~g}$ and the length of the head and body as $150 \mathrm{~mm}$.

\section{RESULTS}

\subsection{Weaning}

A proportion of the younger cubs had milk in their stomachs which appeared as a congealed white paste. Litters were aged from head \& body lengths on the basis of the fitted regressions in Fig. 1 (reconverted there to curves). This shows that cubs start to be weaned during the fourth week of life (Fig. 2), at a head and body length of between 250 and $350 \mathrm{~mm}$ and a weight of 0.4 and $0.8 \mathrm{~kg}$. Weaning takes approximately 10 days, although one exceptional litter had milk in their stomachs at 7 weeks (Fig. 2).

\subsection{Differences in Diet between Regions}

Rabbits, hares and birds (mainly game birds and domestic fowl, but also with some pigeons and small passerines) form the largest part of the diet in the North-east, whereas lambs and Microtus are most important in the West (Table 1). These results are similar to the diets of adults from the same areas during the spring and summer ( $\mathrm{K}$ ol b \& If ews on, 1979). A direct comparison with the frequency of stomach 
contents in adults during April, May and June shows no statistically significant differences.

\subsection{Comparison of Growth Curves}

The rate of growth of litters was similar in the two regions (Table 2). However there is a highly significant difference in the position of the two sets of curves, indicating a later breeding season in the West (Table 2, Fig. 1).

Table 1

The percentage frequency of occurrence of food items in the stomachs of litters of fox cubs killed in two areas of Scotland. $p$ : probability of difference being due to chance from $2 \times 2$ contingency tables.

\begin{tabular}{|c|c|c|c|c|c|c|}
\hline M & $\begin{array}{l}\text { in stc } \\
\text { N.E. } \\
38^{1}\end{array}$ & $\begin{array}{c}\mathrm{h} \text { cont } \\
\text { West } \\
32^{1}\end{array}$ & $\mathrm{p}$ & $\begin{array}{c}\text { Total sto } \\
\text { N.E. } \\
38^{1}\end{array}$ & $\begin{array}{c}\text { mach con } \\
\text { West } \\
32^{1}\end{array}$ & $\mathrm{p}$ \\
\hline Lagomorph & 76 & 6 & 0.001 & 87 & 19 & 0.001 \\
\hline Microtus & 5 & 28 & 0.05 & 16 & 41 & 0.05 \\
\hline Other small mammal & 0 & 3 & n.s. & 11 & 6 & n.s. \\
\hline Lamb & 2 & 38 & 0.001 & 5 & 41 & 0.001 \\
\hline Deer & 0 & 6 & n.s. & 0 & 9 & n.s. \\
\hline Fox cub & 0 & 13 & n.s. & 0 & 13 & n.s. \\
\hline Bird & 18 & 9 & n.s. & 68 & 28 & 0.01 \\
\hline Insect & 0 & 0 & n.s. & 8 & 6 & n.s. \\
\hline Vegetable & 0 & 0 & n.s. & 21 & 6 & n.s. \\
\hline Misc. & 0 & 0 & n.s. & 3 & 3 & n.s. \\
\hline
\end{tabular}

1 Number of litters with solid food in stomachs

Table 2

Analysis of covariance from regressions of Gompertz conversion factors for mean head and body length and weight of litters on date for the North-east and West of Scotland.

\begin{tabular}{lccccccc}
\hline & \multicolumn{3}{c}{ Comparison of slope } & \multicolumn{3}{c}{ Comparison of elevation } \\
& F & d.f & $p$ & F & d.f. & $p$ \\
\hline $\begin{array}{l}\text { Head and body length } \\
\text { Weight }\end{array}$ & 1.896 & 1,120 & n.s. & 34.617 & 1,121 & $<0.00001$ \\
\hline
\end{tabular}

\subsection{Breeding Season}

The points at which the growth curves intercept the time axes for birth length and weight give an estimate of the mean date of birth in each population. This is between a week and a fortnight later in the West than in the North-east (Table 3). The estimate depends on the growth curve used. The weight curve is nearer its lower tail and is probably less reliable for extrapolation. The limits to the breeding season have been estimated by extrapolating extreme litter values back 
to birth size and weight using average growth. Because of the spread in distribution among older animals only the lower half of each data set has been used. This shows that litters are being born over a period of 6 to 7 weeks (Table 3).

Table 3

Estimated dates of birth for litters from the North-east and West of Scotland, assuming a length at birth of $150 \mathrm{~mm}$ and a weight of $100 \mathrm{~g}$.

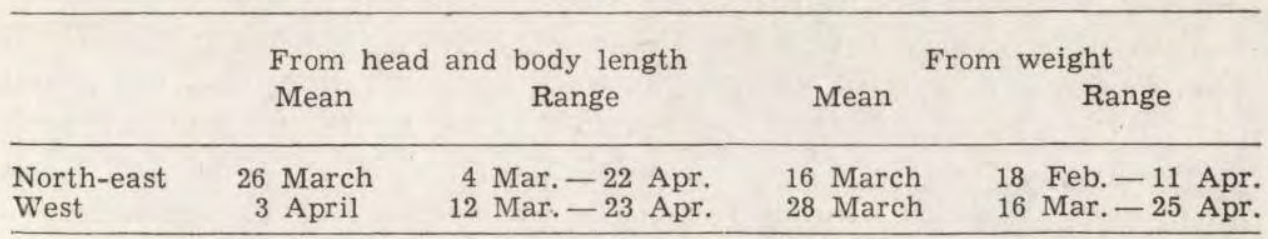

\section{DISCUSSION}

The detailed conclusions presented here about dates of breeding and age of weaning depend upon assumptions such as conformity to a particular growth model, a standard weight and length at birth and a growth rate in all litters resembling the average for the population. Some of these conclusions can be checked against independent results. $\mathrm{Kolb}$ \& Hew Son (1980) give figures for estimated dates of conception for vixens from the same areas, based on fitting the size of embryos to a growth curve. If the gestation period for foxes is taken as 53 days (L loy d, 1977) then means dates of birth can also

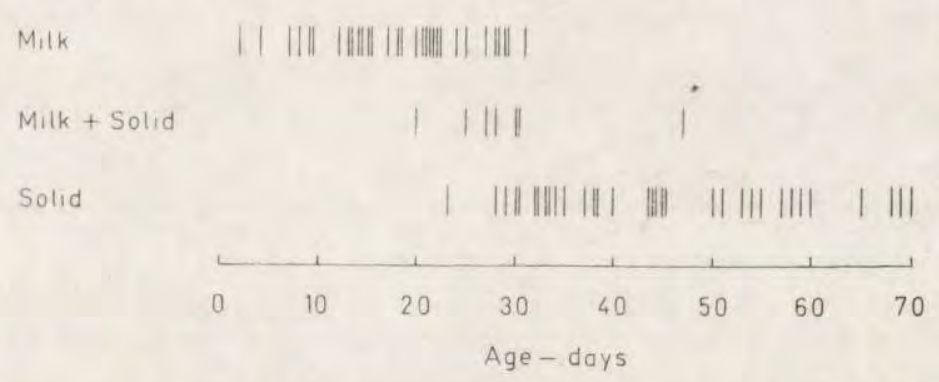

Fig. 2. The stomach contents of litters of young fox cubs. Age has been estimated from mean head and body length assuming average growth as in Fig. 1 and a head and body length at birth of $150 \mathrm{~mm}$.

be estimated. These are 27 March for North-east Scotland and 10 April for the West which are in reasonable agreement with figures in Table 3 for dates estimated from mean head and body length for litters. Lloyld (1977) states that weaning begins at 4 to 5 weeks and is completed at 6 to 7 weeks. However other authors say that weaning 
is accomplished between the third and fourth week ( $\mathrm{Englund,1969;}$ $\mathrm{S}$ a rge an t, 1978) which is more consistent with our results. Suggestions that suckling goes on for very much longer, such as 8 to 10 weeks (M a thews, 1960), are probably in error.

The two main conclusions of this study are that the diet of cubs is distinctly different on the two sides of Scotland and that foxes breed later in the West than in the North-east. Cubs are eating essentially the same foods as adults in the two regions and the same considerations apply. In particular lambs are the most important food in the West. This is the case with the adults as well, although they also eat sheep carrion (Kolb \& H ews o n, 1979). Clearly lambs are carried back preferentially to feed cubs and in the West and North-west they form up to $60 \%$ of remains found at dens ( $\mathrm{H} \mathrm{e} \mathrm{w} \mathrm{s} \mathrm{o} \mathrm{n}, 1979$ ). Howewer lambs only from about $40 \%$ of the diet (Table 1 ) and it is probable that many smaller items that are brought to cubs, such as voles, are not found in den litter. In addition it has yet to be established what proportion of these lambs are fresh kills of healthy animals as opposed to scavenged carrion, or result from attacks on lambs too weak to survive.

Previous descriptions of variation in the breeding season of foxes have concentrated on changes with latitude. Foxes from more northerly populations breed progressively later in the year and although the proximate factors determining the onset of spermatogenesis and ovulation are not known it is pressumed that there is a general adaptation to produce cubs during the most beneficial season for weaning and rearing (Lloyd \& Englund, 1973). Latitude can be excluded as a factor in this study. There are differences in climate between the twu areas, the North-east being drier and having more severe winters (M a n ley, 1952) but it is not easy to see how these can explain the differences in breeding. The main foods of adults and cubs in the North-east are rabbits and mountain hares, both of which are available to some extent during the winter and spring and both of which start breeding relatively early in the year (L lo y d, 1977; H e w s o n, 1977). However in the West the most important food during the spring is lamb which is only present for a limited period. Lambing in hill areas is late compared to other parts of Scotland and generally starts in April (Co p pock, 1976). On one intesively studied estate in the extreme West of Scotland most lambs were born during the first week in May (Hewson \& Verkaik, in prep). Therefore foxes in the West seem to be without a substantial food supply for rearing cubs during the early spring and most probably breeding is delayed as a result.

Acknowledgements: We would like to thank all those gamekeepers, forestry ranges and shepherds who supplied us with litters of cubs during the study, 


\section{REFERENCES}

1. Coppock J. T., 1976: An Agricultural Atlas of Scotland. John Donald, Edinburgh.

2. Englund J., 1969: The diet of fox cubs (Vulpes vulpes) in Sweden. Viltrevy, 6: $1-39$.

3. E w e r R. F., 1973: The Carnivores, Weidenfeld \& Nicolson, London.

4. He w s on R., 1977: Mountain Hare. [In: Corbet, G. B. \& Southern, H. N. (Ed); "The Handbook of British Mammals «]. Blackwell Sci. Publ.: 140-150. Oxford.

5. H e w s o n R., 1979: Foxes in Scotland. Scott. Wildl., 15: 19-23.

6. Kolb H. H. \& Hews on R., 1979: Variation in the diet of foxes in Scotland. Acta theriol., 24: 69-83.

7. Kolb H. H. \& Hews on R., 1980: A study of fox populations in Scotland from 1971 to 1976. J. appl. Ecol., 17: 7-19.

8. La yne J. N. \& McKeon W. H., 1956: Notes on the development of the red fox fetus. N. Y. Fish and Games J., 3: 120-128.

9. L loy d H. G., 1977: Fox. [In: Corbet, G. B. \& Southern, H. N. (Ed); »The Handbook of British Mammals«]. Blackwell Sci. Publ.: 311-320. Oxford.

10. L 10 y d H. G., 1977: Rabbit. [In. Corbet, G. B. \& Southern, H. N. (Ed); "The Handbook of British Mammals"]. Blackwell Sci. Publ.: 131-139. Oxford.

11. Lloyd H. G. \& Englund J., 1973: The reproductive cycle of the red fox in Europe. J. Reprod. Fert., Suppl. 19: 119-130.

12. M a n le y G., 1952: Climate and the British Scene. Collins, London.

13. M a t thews L. H., 1960: British Mammals. Collins: 1-410. London.

14. Ricklefs R. E., 1967: A graphical methods of fitting equations to growth curves. Ecology, 48: 978-983.

15. Sargeant A. B., 1978: Red fox prey demands and implications to prairie duck management. J. Wildl. Manage., 42: 520-527.

Accepted, April 15, 1980.

H. H. KOLB i R. HEWSON

\section{POKARM I WZROST SZCZENIĄT LISA W SZKOCJI}

Streszczenie

Badania przeprowadzono na lisach odstrzelonych przez myśliwych i służbę leśną w latach 1971-1976, w dwóch różnych regionach Szkocji. Każdy lisek był ważony i mierzony, a treść żołądkową pobierano do dalszej analizy. Analiza treści żcłądkowej wykazała, że młode liski z północno-wschodniej Szkocji odżywiają się głównie królikami i zającami, podczas gdy na zachodzie Szkocji jedzą one jagnięta i norniki (Tabela 1; Rycina 2). Tempo wzrostu młodych jest takie samo w obu regionach (Rycina 1), lecz szczenięta w zachodniej części rodzą się średnio tydzień do dwóch tygodni później niż w regionie północno-wschodnim (Tabele 2,3). Sugeruje to, że w omawianych regionach występuje różny okres dostępności podstawowego pokarmu, 